\title{
ANALISIS KUALITAS PELAYANAN PADA PERPUSTAKAAN DI BADAN PUSAT STATISTIK KOTA SURABAYA
}

\author{
Prasetyo Isbandono \\ Isbandonoprasetyo @ gmail.com \\ Dhiah Ayu Pawestri \\ dhiaha7@gmail.com
}

\begin{abstract}
ABSTRAK
Penyelenggaraan pelayanan publik diharapkan dapat memberikan pelayanan yang sesuai dengan kebutuhan dan perubahan di berbagai bidang kehidupan. Penyelenggaraan pelayanan publik yang baik akan menambah rasa percaya masyarakat terhadap penyedia jasa. Badan Pusat Statistik (BPS) Kota Surabaya adalah salah satu instansi pemerintah yang menyediakan pelayanan publik melalui Pelayanan Statistik Terpadu (PST)/Perpustakaan. Penelitian ini bertujuan untuk mendeskripsikan kualitas pelayanan pada perpustakaan di BPS Kota Surabaya. Penelitian ini menggunakan jenis penelitian deskriptif dengan menggunakan pendekatan kualitatif. Fokus penelitian ini berpacu pada fokus penelitian yang digunakan BPS untuk mengevaluasi kualitas pelayanan setiap tahun. Terdapat lima dimensi dari teori Prasurarman yang menjadi fokus penelitian, yaitu dimensi Responsivennes (daya tanggap), Assurance (jaminan), Tangible (fisik), Empathy (empati), dan Reliability (keandalan). Teknik pengumpulan yang dilakukan melalui tiga tahap, yaitu observasi, wawancara dan dokumentasi. Dan analisis data dalam penelitian ini menggunakan tiga komponen yang terdiri dari reduksi data, penyajian data, dan penarikan kesimpulan. Hasil penelitian yang terkait didalam lima dimensi kualitas pelayanan publik yaitu, responsivennes (daya tanggap) keluhan pengunjung belum semuanya direspon dengan baik oleh pihak BPS Kota Surabaya, assurance (jaminan) pengunjung masih mengeluhkan kecepatan petugas dalam melayani, tangible (fisik) prasarana untuk duduk tidak mencukupi ketika pengunjung datang secara bersamaan, empathy (empati) pengunjung sudah merasa puas mengenai perhatian petugas, reliability (keandalan) masih ada data yang belum terpublikasi sesuai waktu yang telah ditetapkan. Saran yang dapat diberikan kepada BPS Kota Surabaya adalah penataan kembali mengenai peletakan kotak saran yang dapat dilihat pengunjung secara langsung, memaksimalkan bantuan dari mahasiswa Praktek Kerja Lapangan (PKL) untuk membantu melayani pengunjung, penambahan prasarana tempat duduk dan sikap tegas pemimpin membuat jadwal publikasi data secara berkelanjutan.
\end{abstract}

Kata Kunci : Kualitas, Pelayanan, Perpustakaan

\section{ABSTRACT}

The delivery of public services is expected to provide services that are appropriate to the needs and changes in various fields of life. Good public service delivery will increase public trust in service providers. The Surabaya Central Statistics Agency (BPS) is one of the government agencies that provide public services through the Integrated Statistics Service (PST) / Library. This study aims to describe the quality of service in libraries in BPS Surabaya. This research uses a descriptive type of research using a qualitative approach. The focus of this research is driven by the focus of research used by BPS to evaluate the quality of service each year. There are five dimensions of Prasurarman's theory that are the focus of research, namely the dimensions of Responsiveness, Assurance, Tangibles, Empathy, and Reliability. The collection technique is carried out through three stages, namely observation, interview, and documentation. And data analysis in this study uses three components consisting of data reduction, data presentation, and concluding. type of descriptive research using a qualitative approach. The focus of this research is driven by the focus of research used by BPS to evaluate the quality of service each year. There are five dimensions of Prasurarman's theory that are the focus of research, namely the dimensions of Responsiveness, Assurance, Tangibles, Empathy, and Reliability. The collection technique is carried out through three stages, namely observation, interview, and documentation. And data analysis in this study uses three components consisting of data reduction, data presentation, and concluding. The results of research related to the five dimensions of public service quality, namely, the responsiveness of visitor complaints have not all been responded to properly by the BPS of Surabaya City, visitors' assurance still complains about the speed of officers in serving, tangible infrastructure to sit insufficient when visitors come together, empathy visitors have satisfied with the officers' attention, reliability still has data that have not been published in accordance with the time specified. Suggestions that can be given to BPS Surabaya are a rearrangement of the placement of suggestion boxes that can be seen by visitors directly, maximizing assistance from Field Work Students (PKL) to help serve visitors, adding seating infrastructure and a strict attitude of leaders to make a schedule of data published in a way sustainable.

Keywords: Quality, Service, Library 


\section{PENDAHULUAN}

Pemerintahan dibentuk untuk memenuhi kebutuhan masyarakat dalam hal pelayanan publik. Pemerintahan juga berkedudukan sebagai organ yang mengorganisir terselenggaranya pelayanan publik. Pengorganisiran pelayanan publik diharapkan dapat meningkatkan kesejahteraan di berbagai bidang kehidupan. Pelayanan publik menurut UU No.25 Tahun 2009 pasal 1 ayat 1 diartikan sebagai rangkaian kegiatan pemenuhan kebutuhan sesuai dengan peraturan perundang-undangan bagi setiap warga negara atas barang/jasa yang disediakan oleh penyelenggara pelayanan. Diterbitkannya undang-undang pelayanan publik bertujuan untuk memberikan kepastian hukum dalam hubungan antara masyarakat dengan penyelenggara pelayanan. Kepastian hukum dapat mewujudkan batasan serta hubungan yang jelas mengenai hak dan kewajiban seluruh pihak terkait dengan penyelenggaraan pelayanan publik.

Instansi pemerintah memiliki berbagai macam jenis pelayanan yang diberikan kepada pengguna layanan. Jenis pelayanan yang diberikan pemerintah menurut Hardiansyah (2011:23) terdapat tiga jenis pelayanan publik, yaitu kelompok pelayanan administratif, kelompok pelayanan barang dan kelompok pelayanan jasa. Kelompok pelayanan administratif merupakan pelayanan yang menghasilkan berbagai produk bentuk dokumen resmi yang dibutuhkan oleh publik, kelompok pelayanan barang merupakan pelayanan yang menghasilkan bentuk/jenis barang yang digunakan oleh publik, dan kelompok pelayanan jasa merupakan pelayanan yang menghasilkan bentuk jasa yang dibutuhkan publik.

Badan Pusat Statistik (BPS) Kota Surabaya adalah salah satu instansi pemerintah yang menyediakan pelayanan publik. Pelayanan publik yang dapat diberikan adalah data lapangan setelah melalui proses pengolahan. Data tersebut akan dipublikasikan melalui website resmi BPS Kota Surabaya maupun buku yang diterbitkan. Buku yang telah diterbitkan dapat ditemukan pada Pelayanan Statistik Terpadu (PST) atau lebih dikenal dengan perpustakaan.

Seksi Integrasi Pengelolaan dan Diseminasi Statistik (IPDS) adalah salah satu seksi yang berada di BPS Kota Surabaya. Seksi IPDS bertugas mengolah semua data dari seksi lain untuk dipublikasikan. Seksi IPDS juga berkewajiban mempublikasikan data ke website resmi BPS Kota Surabaya sesuai dengan waktu yang telah ditetapkan. Data yang dipublikasikan pada halaman resmi bertujuan untuk memudahkan penguna jasa mendapatkan data dengan cepat. Selain melalui website resmi, data yang telah diolah juga dapat ditemukan pada perpustakaan didalam BPS Kota Surabaya. Hal ini memudahkan pengguna jasa mendapatkan data secara langsung ketika data tersebut belum semuanya terpublikasi di website resmi. Pegawai yang bertugas pada perpustakaan merupakan bagian dari seksi IPDS. Penempatan pegawai IPDS didalam perpustakaan bermaksut untuk membantu pengguna jasa dalam hal menjelaskan data yang mereka butuhkan.

Perpustakaan di BPS Kota Surabaya menjadi tempat rujukan data dari seluruh aktivitas di Surabaya. Selain menjadi tempat rujukan data, perpustakaan juga berfungsi untuk mendapatkan jenis pelayanan lainnya. Pelayanan yang dapat diberikan, yaitu layanan perpustakaan tercetak, layanan perpustakaan digital, layanan penjualan buku, layanan data mikro/peta digital/ softcopy publikasi, layanan konsultasi data statistik, serta layanan konsultasi dan rekomendasi kegiatan statistik. Hal ini akan membuat pengguna layanan mengukur setiap kualitas pelayanan yang diberikan.

Kualitas pelayanan merupakan presepsi pengguna jasa dari realitas pemberian pelayanan. Kualitas pelayanan dapat diukur melalui daya tanggap, ketepatan waktu, kemampuan dan sarana prasarana. Kualitas pelayanan dapat dikatakan baik apabila harapan pengguna jasa terpenuhi. Sebaliknya, kualitas pelayanan buruk ketika harapan pengguna jasa tidak terpenuhi dengan baik.

Pelayanan publik yang diselenggarakan oleh BPS Kota Surabaya belum sepenuhnya memenuhi harapan pengguna jasa. Hal ini dibuktikan dengan jumlah petugas perpustakaan tidak sebanding dengan jumlah pengunjung perpustakaan. Dari hasil perhitungan, intensitas pengunjung perpustakaan pada 3 bulan terkahir mencapai 48 orang. Jumlah tersebut berbanding terbalik dengan satu orang petugas perpustakaan. Keterbatasan petugas perpustakaan dapat memperlambat waktu pelayanan.

Keluhan lain disampaikan oleh pengujung website mengenai keterlambatan publikasi data. Selain itu eluhan lain disampaikan mengenai sikap petugas perpustakaan terhadap rekan kerja didalam perpustakaan. Keberadaan pegawai lain mengakibatkan kursi pengunjung sudah ditempati oleh rekan kerja lain. Hal ini menyebabkan pengunjung perpustakaan menunggu dengan berdiri. Keluhan yang dirasakan pengunjung belum terespon dengan baik. Pengunjung perpustakaan terlalu pasif ketika mereka sudah mendapatkan data.

\section{METODE PENELITIAN}

\section{Jenis penelitian}

Penelitian ini menggunakan jenis penelitian deskriptif dengan pendekatan kualitatif. Penelitian kualitatif dimaksud sebagai jenis penelitian yang temuan-temuannya tidak diperoleh melalui prosedur statistik atau bentuk hitungan lainnya (Gunawan 2016:80). Dari penjelasan ketiga para ahli tersebut penelitian kualitatif merupakan penelitian secara alamiah bukan penelitian yang merumuskan hipotesis. Sedangkan data yang dihasilkan melalui pendekatan kulitatif tipe deskritif berupa kata-kata atau tulisan dari hasil wawancara pengunjung perpustakaan dan perilaku pegawai yang diamati.

\section{Fokus Penelitian}

Fokus penelitian ini berpacu pada fokus penelitian yang digunakan BPS untuk mengevaluasi kualitas pelayanan setiap tahun. Terdapat lima dimensi dari teori Prasurarman yang menjadi fokus penelitian, yaitu :

A. Responsiveness (daya tanggap)

Kesanggupan membantu menyediakan pelayanan, menjelaskan, dan tanggap terhadap keluhan konsumen.

B. Assurance (jaminan)

Bentuk kepastian data dan kemampuan memberikan pelayanan yang mudah, cepat serta tepat.

C. Tangible (fisik) 
Kualitas pelayanan yang berupa sarana fisik perkantoran, alat bantu pelayanan dan ruang tunggu.

D. Empathy (empati)

Sikap tegas dan penuh perhatian dari pegawai terhadap konsumen.

E. Reliability (keandalan)

Kemampuan dan keandalan menyediakan pelayanan secara profesional

\section{Sumber Data}

Sumber data merupakan dasar yang digunakan sebagai bahan untuk mengolah data. Ada dua macm sumber pengumpulan data yang penulis gunakan dalam penelitian ini yakni :

1. Data primer, meliputi wawancara dengan petugas perpustakaan dan pengunjung perpustakaan.

2. Data skunder, meliputi foto yang berkaitan dengan kondisi lapangan. Kemudian foto tersebut dapat dijadikan sebagai gambaran nyata keadaan disana dengan membandingkan hasil wawancara yang telah dilakukan.

\section{Instrumen Penelitian}

Instrumen penelitian adalah semua alat yang digunakan untuk menyelidiki suatu masalah atau mengumpulkan datadata secara sistematis serta objectif dengan tujuan memecahkan suatu persoalan atau menguji hipotesi. Instrumen yang digunakan dalam penelitian ini menggunakan instrumen yang berkaitan dengan metode kualitatif. Metode tersebeut anatara lain pedoman wawancara yang berisi pertanyaan yang akan ditanyakan ke pada informan lapngan. Selain itu buku catatan yang digunakan untuk mencatat hasil wawancara, dan alat komunikasi seperti smarphone yang dapat digunakan untuk merekam ketika proses wawancara berlangsung serta mengambil data berupa foto.

\section{Teknik Pengumpulan Data}

Teknik pengumpulan data yakni dengan pengumpulan data dari sumber data yang diatas dan cara-cara yang sesuai dengan model penelitian kualitatif. Sejalan dengan hal itu teknik pengumpulan data kualitatif dapat dilakukan menggunakan cara observasi, wawancara, dokumentasi dan triangulasi/gabungan. Dalam penelitian ini memakai teknik pengumpulan data sebagai berikut :

1. Observasi

Observasi yang dilakukan dilapangan melalui pengamatan secara langsung terkait pelayanan yang diberikan yang berada di perpustakaan BPS Kota Surabaya. Selain itu observasi dapat dilakukan dengan melihat kondisi sekitar mengenai sarana yang disediakan serta kesiapan pegawai dalam hal melayani dan melakukan tanya jawab dengan peneliti.

2. Wawancara

wawancara akan dilakukan dengan petugas perpustakaan BPS Kota Surabaya dan pengunjung perpustakaan BPS Kota Surabaya. Wawancara tersebut akan membahas mengenai kepuasan pelayanan ketika berkunjung pada perpustakaan BPS Kota Surabaya. Informan terkait pengunjung perpustakaan dan petugas perpustakaan sudah tertera pada sumber data.

3. Dokumentasi

Dokumentasi yang diperoleh untuk ini yaitu berupa foto mengenai kondisi sarana dan prasarana dalam menunjang keberlangsungan pelayanan yang ada di perpustakaan BPS Kota Surabaya. Hal tersebut dapat menjadi bukti nyata kesiapan BPS dalam melakukan pelayanan.

\section{Teknik Analisis Data}

Secara garis besar menurut Miles dan Huberman dalam Sugiyono (2016: 337) menyatakan bahwa aktivitas dalam analisis data kualitatif dilakukan secara interaktif dan berlangsung secara terus menerus sampai tuntas, sehingga datanya sudah jenuh. Aktivitas dalam analisis data seperti data reduction, data display, dan conclusion drawing/verification. Dari teori tersebut dapat disimpulkan bahwa teknik analisis data dalam penelitian menggunakan empat metode yakni pengumpulan data, reduksi data, display data dan kesimpulan/verivikasi

1. Pengumpulan data

Pengumpulan data adalah menjadikan satu variabel-variabel yang di perolah dari lapangan. Pengumpulan data dalam penelitian ini adalah hasil observasi mengenai kualitas pelayanan yang diberikan pada perpustakaan di Badan Pusat Statistik Kota Surabaya. Selain itu wawancara yang telah dilakukan kepada beberapa pegawai perpustakaan guna memperkuat data yang diperoleh. Hasil dari wawancara juga lebih diperkuat dengan pengumpulan dokumentasi berupa foto tentang kondisi dilapangan secara langsung.

2. Reduksi data

Reduksi data merupakan pemilihan dari beberapa data yang diperoleh kedalam satu pokok bahasan penting. Dalam penelitian pada perpustakaan di Badan Pusat Statistik Kota Surabaya memperoleh data dari hasil observasi, wawancara, serta dokumentasi dengan pegawai yang bertanggung jawab menangani perpustakaan. Reduksi data dapat dilakukan dengan merangkum hasil observasi, wawancara serta dokumentasi ke dalam hal-hal yang dianggap penting serta menentukan tema dan pola penelitian.

3. Display data

Tahap selanjutnya setelah reduksi data yaitu proses display data. Penyajian data bertujuan untuk memudahkan, memahami apa yang terjadi serta merencanaka pekerjaan selanjutnya berdasarkan apa yang telah dipahami tersebut. Proses penyajian data dalam penelitian kualitatif dilakukan dalam bentuk uraian singkat, bagan, hubungan antar kategori, flowchart dan sejenisnya. Pada penelitian ini penyajian data berupa informasi yang berasal dari hasil penelitian dengan metode wawancara, observasi dan dokumentasi akan di rangkum sesuai dengan kondisi lapangan saat melakukan penelitian.

4. Kesimpulan/verivikasi 
Langkah keempat setelah kesimpulan/verivikasi yaitu menarik kesimpulan dari semua informasi yang telah didapat saat melakukan penelitian. Penarikan kesimpulan pada penelitian ini berasal dari data yang telah diperoleh baik berupa dokumentasi, foto, dan hasil wawancara di Kantor Badan Pusat Statistik Kota Surabaya.

\section{HASIL DAN PEMBAHASAN}

Setiap tahunya BPS Kota Surabaya melakukan pengevaluasian terhadap kualitas pelayanan pada PST (Pelayanan Statistik Terpadu)/Perpustakaan. Menurut Zaitmal, Prasurarman \& Berry (dalam Semil, 2018:47) kualitas pelayanan adalah harapan atau keinginan konsumen terhadap kenyataan yang mereka alami. Definisi tersebut berorientasi pada pengguna layanan, namun bukan berati dalam menentukan kualitas pelayanan penyedia jasa pelayanan harus menuruti semua keinginan konsumen. Dalam pengevaluasian kualitas pelayanan publik, BPS melakukan pengevaluasian menggunakan dimensi kualitas pelayanan publik dari Prasurarman. Hasil evaluasi dari kualitas pelayanan akan dipublikasikan melalui bukunya Analisis Hasil Survei Kualitas Data atau yang biasa disebut dengan SKD (Survei Kebutuhan Data). Dimensi yang digunakan untuk menilai kualitas pelayanan yang ada pada perpustakaan BPS Kota Surabaya sebagai berikut :

\section{Responsiveness (daya tanggap)}

Dimensi ini merupakan kesanggupan membantu menyediakan pelayanan yang cepat dan tepat kepada pengunjung. Membantu menyampaikan informasi yang berkaitan dengan keperluan pengunjung secara jelas. Membiarkan pengunjung menunggu terlalu lama tanpa alasan yang jelas dapat membuat presepsi yang negatif terhadap kualitas pelayanan. Selain itu daya tanggap dalam proses pelayanan akan mempengaruhi hasil kinerja pegawai. Sebab ketika proses pelayanan didasari oleh keinginan dan komitmen untuk melaksanakan pelayanan dengan baik, maka akan tercipta peningkatan kualitas pelayanan yang semakin baik. Pelayanan publik yang ada di perpustakaan BPS Kota Surabaya sudah menerapkan dimensi responsiveness beserta indikatornya. Indikator tersebut antara lain :

a. Membantu pengunjung yang ingin mendapatkan data

Dari 10 informan yang mengujungi perpustakaan 9 diantaranya direspon dengan baik dan 1 pengunjung mengalami penolakan karena waktu pelayanan yang terlalu mepet dengan jam kerja.

b. Membantu pengunjung mendapatkan pelayanan Dari 10 informan yang mengunjungi perpustakaan semuanya memiliki prosedur pelayanan yang sama untuk mendapatkan pelayanan.

c. Semua keluhan pengunjung direspon oleh petugas

Dari 10 informan yang mengunjungi perpustakaan, semua keluhan belum terespon dengan baik. Hal tersebut dibuktikan dengan masih adanya keluhan yang sama.

Pada hasil penelitian dan wawancara yang telah dilakukan kepada pengunjung perpustakaan
BPS Kota Surabaya, masih terdapat keluhan mengenai pelayanan yang diberikan. Keluhan dari pengunjung tidak semuanya disampaikan kepada pihak BPS Kota Surabaya. Pengunjung perpustakan masih tidak mengetahui bagaimana cara untuk melaporkan keluhan tersebut. Adapun cara yang mereka lakukan dengan menyampaikan keluhan tersebut secara langsung setelah mereka selesai mendapatkan pelayanan.

Keluhan pengunjung yang telah direkap pada hasil kuisioner telah disampaikan kepada BPS Pusat. Namun, respon dari BPS Pusat yang membuat keluhan tersebut belum teratasi dengan baik. Sehingga BPS Kota Surabaya tidak berani mengambil tindakan sendiri ketika belum ada perintah dari BPS Pusat. Untuk sementara ini keluhan yang selalu teratasi adalah keluhan mengenai kelengkapan data yang ada di BPS Kota Surabaya. Saran yang dapat diberikan oleh pihak BPS Kota Surabaya dapat melalui saran untuk mencari di BPS Provinsi maupun instansi terkait.

2. Assurance (jaminan)

Dimensi ini merupakan jaminan pegawai memberikan kepastian data dan memberikan pelayanan dengan cepat serta tepat. Pemberian jaminan tersebut guna untuk menumbuhkan rasa kepercayaan pengunjung. Berikut 2 indikator mengenai dimensi assurance :

a. Petugas memberikan kepastian data

Dari 10 responden yang mengujungi perpustakaan 4 diantaranya diberikan kesempatan untuk mencari data menggunakan sistem pencarian, sedangkan 4 responden lain tidak mendapatkan kesempatan dengan alasan berdekatan dengan waktu pulang kerja, hanya 1 orang yang diberi kesempatan mencari data dan memang tidak diberi kesempatan. Dua responden lain tidak menanggapi pertanyaan peneliti.

Hasil penelitian dan wawancara yang telah dilakukan oleh pengungjung dan petugas perpustakaan, semua pengunjung sudah mendapatkan data sesuai kebutuhannya. Namun, masih ada pengunjung yang tidak ikut serta dalam pencarian data. Hal tersebut dapat membuat rasa percaya akan koleksi buku maupun file data yang ada di perpustakaan tidak maksimal.

b. Petugas memberikan pelayanan dengan cepat dan tepat

Dari 10 responden yang mengunjungi perpustakaan 2 diantaranya mengeluhkan kecepatan dalam hal melayani sedangkan 8 responden lainnya sudah merasa cepat dalam hal pelayanan.

Penerapan dimensi assurance belum sepenuhnya diterapkan dengan baik. Hal itu dibuktikan masih adanya keluhan dari pengunjung terkait kecepatan pegawai dalam melayani. Dari hasil penelitian kecepatan pegawai berkurang ketika pegawai mendapatkan pengunjung yang datang secara bersamaan. 


\section{Tangible (fisik)}

Dimensi ini merupakan kemampuan penyedia layanan dalam menyiapkan sarana dan prasarana fisik perusahaan. Sarana dan prasarana dapat menjadi eksistensi bukti nyata dari pelayanan yang diberikan oleh penyedia jasa. Fasilitas fisik tempat pelayanan meliputi teknologi (peralatan dan perlengkapan yang dipergunakan) serta penampilan pegawai dalam melayani pengunjung. Secara singkat dapat diartikan sebagai penampilan fasilitas fisik dan peralatan. Pada penelitian ini, dimensi tangible ditentukan oleh tiga indikator yaitu :

a. Penampilan pegawai

Dari 10 responden yang mengujungi perpustakaan semua mengatakan pegawai telah berpenampilan sesuai dengan seragam yang dikenakan, sopan dan rapih.

Hasil penelitian yang telah dilakukan, pegawai perpustakaan sudah berpenampilan sesuai dengan ketetapan. Penampilan pegawai ini dapat menjadi penilaian utama terhadap pelayanan yang ada diperpustakaan tersebut. Kesesuaian seragam yang dikenakan setiap harinya juga menambah penilian bahwa semua pegawai BPS Kota Surabaya menaati peraturan yang telah ditetapkan.

b. Kemudahan dalam proses pelayanan

Dari 10 responden yang mengunjungi perpustakaan semua mengatakan fasiltas sebagai penunjang kemudahan proses pelayanan sudah tersedia dengan baik.

Dari hasil wawancara membuktikan pengunjung tidak kesulitasn untuk mendapatkan pelayanan yang ada pada perpustakaan tersebut. Untuk pencarian data pengunjung telah disedikan komputer sebagai sistem pencarian. Pada sistem pencarian, pengunjung hanya memasukan kata kunci yang ingin dicari. Sehingga pengunjung tidak perlu mencari buku satu persatu pada rak buku yang telah disediakan.

c. Kenyamanan tempat melakukan pelayanan Dari 10 responden yang mengunjungi perpustakaan semua mengatakan sarana dan prasarana yang disediakan sudah memenuhi. Namun masih ada masukan dari pengunjung terkait kurangnya tempat duduk, keluasan tempat dan suasana tempat yang masih kuno.

Dari hasil observasi terdapat CCTV untuk memantau setiap kegiatan pada perpustakaan BPS Kota Surabaya. Tempat parkir yang disediakan juga dapat dipantau langsung oleh security maupun pengunjung perpustakaan. Pengunjung juga dapat menempatkan barang mereka pada loker yang telah disediakan.

Keamanan tempat dan pelayanan telah diterapkan dengan baik oleh perpustakaan BPS Kota Surabaya. Namun dari hasil wawancara pengunjung perpustakaan masih terdapat keluhan mengenai jumlah tempat duduk. Hal ini disebabkan pengunjung yang datang secara kondisional dan masih adanya pegawai lain yang bekerja disana.
Selain itu kesan kuno pada perpustakaan tersebut masih terlihat dengan fasilitas meja kursi menggunakan kayu. Luas ruangan pada perpustakaan juga mempengaruhi kualitas kenyamanan yang ada pada perpustakaan tersebut.

4. Emphaty (empati)

Dimensi ini memberikan perhatian tulus dan bersifat individual atau pribadi yang diberikan kepada pengunjung yang datang. Dengan berupaya memahami keinginan pengunjung dimana penyedia layanan diharapkan memiliki suatu pengertian kepada pengunjung, memahami kebutuhan pengunjung secara spesifik, serta memiliki waktu pengoperasian yang nyaman bagi pengunjung. Secara singkat dapat diartikan sebagai usaha mengetahui dan mengerti kebutuhan pengunjung secara individual. Pada penelitian ini, dimensi emphaty ditentukan oleh tiga indikator yaitu :

a. Mendahulukan kepentingan pengunjung

Dari 10 responden yang mengujungi perpustakaan 9 diantaranya tidak menemui adanya pegawai lain yang bekerja diperpustakaan, sedangkan 1 pengunjung lain menemui adanya pegawai lain bekerja di perpustakaan.

Dari hasil penelitian dan wawancara yang telah dilakukan oleh pengunjung maupun petugas perpustakaan. Petugas perpustakaan sudah mendahulukan pengunjung yang ingin mendapatkan pelayanan. Hal tersebut bebrbeda dengan pendapat pengunjung lain. Pengunjung lain mengatakan masih adanya pegawai lain yang bekerja didalam perpustakaan. Pegawai yang bekerja pada perpustakaan belum mendahulukan pengunjung perpustakaan untuk menempati tempat duduk yang dipersiapkan.

Keberadaan pegawai lain yang berada di dalam perpustakaan dapat membuat fasilitas untuk duduk berkurang. Selain itu pengunjung akan merasa canggung terhadap pegawai lain yang bekerja pada perpustakaan. Hal ini dapat menyebabkan kebutuhan pengunjung serta penjelasan dari petugas tidak tersampaikan dengan baik. Kesadaran dari pegawai lain memang penting untuk menciptakan sebuah pelayanan yang berkualitas

b. Petugas melayani dengan ramah dan sopan

Dari 10 responden yang mengunjungi perpustakaan semua mengatakan petugas menjelaskan data yang mereka cari dengan ramah dan sopan.

Dari hasil wawancara kepada petugas dan pengunjung perpustakaan, petugas sudah menjelaskan data yang mereka butuhkan secara ramah dan sopan. Petugas tidak memandang kemampuan pengunjung sebelah mata. Petugas menganggap itu sebuah kewajiban yang harus dilaksanakan. Pengunjung perpustakaan dapat dengan mudah bertanya ketika mereka belum bisa membaca data dengan baik.

c. Pegawai melayani dengan tidak diskriminatif 
Dari 10 responden yang mengunjungi perpustakaan semua mengatakan tidak ada perbedaan pelayanan antara pengunjung satu dengan pengunjung lainnya.

Dari hasil observasi ketika peneliti melihat catatan pada buku tamu. Pengunjung yang datang pada perpustakaan BPS Kota Surabaya di dominasi dari mahasiswa yang ada di Surabaya. Selain mahasiswa dari Surabaya, adapula mahasiswa dari luar kota Surabaya, instansi swasta dan pihak dari TNI-AL (Tentara Nasional Indonesia-Angkatan Laut). Semua pengunjung yang datang tetap dilayani sesuai dengan nomor urut yang ada pada buku tamu. Petugas perpustakaan tidak mendahulukan pengunjung yang mempunyai derajat sosial yang lebih tinggi.

Hal tersebut dapat menjadi contoh yang baik untuk instansi pemerintah lainnya. Perbedaan pelayanan dapat menyebabkan terhambatnya proses pelayanan dengan pengguna jasa yang lain.

5. Reliability (keandalan)

Dimensi ini merupakan kemampuan penyedia layanan untuk memberikan pelayanan sesuai dengan prosedur secara tepat dan tepat. Keandalan pegawai dalam memberikan pelayanan sangat membantu pengunjung dalam menerima pelayanan secara cepat dan mudah. Keandalan dapat dilihat dari kecermatan pegawai menjelaskan data yang dicari pengunjung, keahlian dan kemampuan pegawai dalam menggunakan alat bantu dalam proses pelayanan. Pada penilitian ini, dimensi reliability ditentukan oleh indikator-indikator sebagai berikut :

a. Kemampuan pegawai dalam melayani pengunjung

Dari 10 responden yang mengujungi perpustakaan 8 diantaranya menganggap kemampuan pegawai sudah baik, sedangkan 2 pengunjung lain menganggap kemampuan petugas dalam menjelaskan data masih kurang jelas dan detail .

Dari hasil penelitian terdapat satu orang petugas yang berada di perpustakaan BPS Kota Surabaya. Hal ini membuat petugas perpustakaan dituntut selain memiliki keahlian dalam kecapatan melayani juga kemampuan dalam hal menjelaskan kebutuhan data pengunjung.

Hasil wawancara membuktikan bahwa petugas perpustakaan sudah memberikan penjelasan secara terperinci. Namun, ada beberapa pengunjung yang kurang paham dari penjelasan yang telah disampaikan oleh petugas perpustakaan. Ketidak pahaman disebabkan karena data yang mereka butuhkan terlalu rumit untuk dicari.

b. Memiliki standar pelayanan yang jelas

Dari 10 responden yang mengunjungi perpustakaan 5 diantaranya sudah mengetahui dan sudah merasa jelas mengenai standar pelayanan yang telah dipajang sedangkan 5 pengunjung lain belum pernah melihat standar pelayanan yang telah ada.

Dari hasil wawancara dengan pengunjung, pengunjung tidak terlalu menanggapi akan standar pelayanan yang ada di perpustakaan BPS Kota Surabaya. Bahka pengunjung perpustakaan tidak mengetahui akan standar pelayanan yang sudah ada di dindinh perpustakaan.

Dari hasil observasi dan wawancara lanjutan yang telah dilakukan. Pengunjung dan petugas perpustakaan sudah menerapkan standar pelayanan yang telah ditentukan. Standar pelayanan tersebut menjelaskan alur pelayanan, biaya pelayanan dan ketentuan lainnya. Mengenai alur pelayanan pengunjung sudah melalui alur pelayanan yang sesuai dengan mengisi buku tamu, menyampaikan kebutuhan dan pulang membawa data yang diperoleh. Terkait biaya pelayanan, tidak ada tarif khusus yang dikenakan oleh petugas perpustakaan kepada setiap pengunjung yang ingin mendapat pelayanan.

c. Menyediakan pelayanan secara profesional

Dari 10 responden yang mengunjungi website resmi BPS Kota Surabaya 5 diantaranya mengatakan data yang mereka cari belum dipublikasikan, 4 pengunjung website mengatakan data yang mereka cari sudah ada dan 1 responden lagi memerlukan layanan konsultasi secara langsung.

Dari hasil wawancara, pengujung masih mengeluhkan data yang dipublikasikan oleh pihak BPS belum sepenuhnya terpublikasi sesuai dengan tahun berjalan. Selain itu kurangnya pengetahuan pengunjung website mengenai bagaimana cara mereka mendapatkan data membuat pengunjung kebingungan. Data yang ada diwebsite tidak semuanya terpublis secara langsung. Terdapat datadata tertentu yang mengaharuskan mereka untuk $\log$ in menggunakan email mereka agar mereka dapat mendapatkan data tersebut.

\section{PENUTUP \\ Simpulan}

Hasil penelitian dan pembahasan, kualitas pelayanan publik pada perpustakaan di BPS Kota Surabaya dapat dinilai dari lima dimensi yang ada pada SKD 2018. Berikut kesimpulan dari kelima dimensi :

1. Dimensi Responsiveness (Daya Tanggap) yang mempunyai indikator merespon pengunjung yang ingin mendapatkan pelayanan, membantu pengunjung mendapatkan pelayanan, dan semua keluhan pengunjung direspon oleh pegawai. Namun ada indikator yang belum sepenuhnya dilaksanakan mengenai keluhan pengunjung belum direspon dengan baik. Hal tersebut dikarenakan pengunjung tidak mengetahui kotak pengaduan yang telah disedikan dan cara melaporkan keluhan tersebut. Selain itu hasil kuisioner yang telah disebarkan belum mendapat respon dari BPS Pusat. Keterlambatan respon dari BPS Pusat membuat BPS Kota Surabaya tidak dapat mengambil tindakan cepat mengenai keluhan pengunjung.

2. Dimensi Assurance (Jaminan) yang mempunyai indikator kepastian data dan pelaksanaan pelayanan dengan cepat serta tepat. Dimensi ini belum sepenuhnya sesuai dengan harapan pengunjung. Namun ada indikator 
yang belum sepenuhnya dilaksanakan mengenai kecepatan pelayanan ketika pengungjung datang secara bersamaan.

3. Dimensi Tangible (Fisik) yang mempunyai indikator penampilan pegawai dalam melayani pengunjung, kemudahan dalam proses pelayanan, dan kenyamanan tempat melakukan pelayanan. Namun ada indikator yang belum sepenuhnya dilaksanakan mengenai kurangnya prasana tempat duduk. Hal tersebut dikarenakan tidak sesuainya jumlah tempat duduk dengan jumlah pengunjung secara kondisional. Selain itu keberadaan pegawai lain yang bekerja pada perpustakaan membuat terbatasnya tempat duduk untuk pengunjung yang datang.

4. Dimensi Empathy (Empati) yang mempunyai indikator mendahulukan kepentingan pengunjung, dan pegawai melayani dengan tidak diskriminatif. Dimensi ini sudah memenuhi keinginan pengunjung, hal tersebut dibuktikan dengan tidak adanya keluhan dari pengunjung perpustakaan terkait dimensi empathy.

5. Dimensi Reliability (Keandalan) mempunyai indikator kemampuan pegawai dalam melayani pengunjung, memiliki standar pelayanan yang jelas dan menyediakan pelayanan profesional terpercaya. Namun ada indikator yang belum sepenuhnya dilaksanakan yaitu keprofesionalan pihak BPS dalam mempublikasikan data tepat waktu.

\section{Saran}

Berdasarkan kesimpulan tersebut, maka dapat diberikan saran sebagai berikut :

1. Dimensi responsiveness merupakan daya tanggap pihak penyedia jasa merespon keluhan pengguna. Merespon keluhan pengunjung dapat dilakukan dengan meletakan kotak saran di tempat yang strategis. Sehingga pengunjung dapat dengan mudah menyampaikan saran untuk perbaikan pelayanan.
2. Dimensi assurance merupakan jaminan kecepatan dan ketepatan penyedia jasa dalam memberikan pelayanan. Satu petugas perpustakaan tidak cukup untuk melayani pengunjung yang datang secara bersamaan. Perpustakaan BPS Kota Surabaya sebaiknya memaksimalkan bantuan dari mahasiswa yang sedang PKL (Praktek Kerja Lapangan) untuk membantu proses pelayanan pada saat pengunjung datang secara bersamaan. Selain menambah pengetahuan mahasiswa PKL, bantuan tersebut juga dapat mempercepat waktu pelayanan. Sehingga pengunjung tidak menunggu terlalu lama.

3. Dimensi tangible merupakan penyediaan sarana dan prasaran untuk menunjang keberlangsungan pelayanan. Dengan intensitas pengunjung secara kondisional, sebaiknya pihak perpustakaan menambah sarana dan prasarana untuk kenyamanan pengunjung perpustakaan.

4. Dimensi reliability merupakan keprofesionalan pihak BPS mempublikasikan data secara tepat waktu. Untuk menghindari keterlambatan, saran dari penulis adalah membuat daftar publikasi yang dapat dilihat oleh pegawai di seksi IPDS. Selain itu, kepala seksi IPDS juga harus saling mengingatkan mengenai jadwal.

\section{DAFTAR PUSTAKA}

Badan Pusat Statistik. 2018. Analisis Hasil Survei Kebutuhan Data 2018. (https://www.bps.go.id/, diunduh 28 Maret 2019)

Gunawan, Imam. 2016. METEDOLOGI PENELITIAN KUALITATIF:Teori dan Praktik. Jakarta: Bumi Aksara

Hardiansyah. 2011. KUALITAS PELAYANAN PUBLIK. Konsep Dimensi, Indikator dan Implementasinya. Yogyakarta: GAVA MEDIA

Republik Indonesia. Undang-Undang Republik Indonesia Nomor 25 Tahun 2009 tentang Pelayanan Publik. Dewan Perwakilan Rakyat Indonesia. Jakarta 
Prasetyo Isbandono: Analisis Kualitas Pelayanan Pada Perpustakaan...

Halaman Ini Sengaja Dikosongkan... 